R. R. Race, Aileen M. Prior and Elizabeth W. Ikin (Brit. Med. J., Feb. 24, 1940). It had already been shown that in some $A B$ cases the factor $B$ is partially dominant to and obscures the $A$ antigen; and that while there tends to be some weakening of the $B$ reaction in group $A B$, it is nothing like so marked or so important as is the suppression of $A$. As there are two types of $A$ antigen, $A_{1}$ and $A_{2}$, a stronger and a weaker, the suppression by $B$ of an already weak $A_{2}$ in the group $A_{2} B$ may result in it only being possible to detect the $A$ factor with powerful anti- $A$ serum, the cells otherwise being diagnosed as group $B$.

Following on the observations recorded, it is shown that the order of decreasing strength of reaction is $A, A_{1} B, A_{2}, A_{2} B$. Further, as the serum from quite a number of $A_{2} B$ cases contains the antibody $\alpha_{1}$, which reacts with $A_{1}$ but not with $A_{2}$ cells, unless appropriate measures are taken, a reaction will result which confirms the diagnosis of group $B$. In view of the significance attached in anthropological classification to the distribution both within a given population and geographically of the elements $A$ and $B$, it is of interest and importance to note that cases diagnosed as $B$ have been found on re-examination to belong to group $A B$, and an inspection of published figures from all parts of the world shows that in a large proportion of the series there is a real deficiency of the numbers in group $A B$. It is possible that herein lies a clue to the explanation of certain anomalies and apparent irregularities to be noted in studies of the groups as racial elements.

\section{The Black Rat in Great Britain}

Nor so long ago it was generally said that the black rat, Rattus rattus, had disappeared from Britain, ousted in unequal contest with the brown new-comer, Rattus norvegicus. But to most naturalists interested in the subject it was known that little centres existed in wide-scattered areas where a black rat could be found if it was wanted. Now Colin Matheson, in an interesting account of results derived from his own observations in Cardiff and from a questionnaire sent to medical officers of health in "approved ports", discloses a somewhat disturbing situation about the black rat, the carrier of the flea, which in its turn disseminates plague (J. Anim. Ecol., $8,76 ; 1939)$. Stringent regulations are in force to ensure that ships are kept free of rats, and that while ships are in port it should be made extremely difficult for inboard rats to make a passage to the shore. The result has been a general decline in the rat population of ships visiting Britain, although a number averaging $6-8$ seems to be the irreducible minimum on rat-infested ships.

On shore, however, in spite of rat-weeks and ratprevention measures, the number of black rats appears to be on the increase, the statistics for thirteen British seaports showing a rise from about 4,110 in 1929 to more than 6,437 in 1934 and 5,362 in 1937. Moreover, the shore companies appear to be extending their range from the neighbourhood of docks to city areas, in some of which they are well established, and are able to maintain themselves without further accessions from the dockyard immigrants. Of the three commonest races of the black rat the most. frequent in British seaports is the typical black form, $R$. $r$. rattus, but curiously enough the brownish $R$. $r$. alexandrinus takes the lead in numbers in London and Plymouth.

\section{Activities of Analytical Chemists}

In his presidential address to the Society of Public Analysts and other Analytical Chemists delivered on March 6, Prof. W. H. Roberts pointed out that there has been much less need in this War than in the last for the formation of ad hoc committees of chemists to deal with problems with which the Government departments found themselves faced, for much had been foreseen and provided for ; and some of the departments had from the outset adopted the course of appointing to their staffs eminent outside chemists, who not only brought to the departments their own expert knowledge but also rendered the departments more accessible to suggestions and representations from outside chemical bodies. The compilation of the National Service Register by the Ministry of Labour, in which the Society had co-operated, had provided the Government with a source of specialized personnel. The conditions of appointment of gas identification officers needs reconsideration, especially in view of the duties now placed upon them in respect of preliminary food tests for gas-contamination. Referring to the Food and Drugs Act of 1938, Prof. Roberts said that the rationing of meat would probably lead to increased consumption of certain other foods, such as sausages and cheese, and regulations governing the content of meat in sausages and of water in cheese (particularly processed cheese) would therefore become very necessary.

The number of analysts and consultants in independent practice has diminished greatly in recent years, Prof. Roberts said, but in the public interest it is important that there should be a strong band of such chemists, not attached to any special interest, and it was therefore necessary to watch closely for cases of unfair competition by publicly supported laboratories. Speaking of the necessity of maintaining a high standard of efficiency amongst analysts, he expressed regret that no English university has yet inaugurated a chair of analytical chemistry, and also suggested that the universities should exercise more rigorous selection to ensure that only students having a real aptitude for the subject should be admitted to their courses. The roll of the Society now includes 886 names. The following officers for the year 1940-41 were elected : President, Dr. E. B. Hughes ; Hon. Treasurer, G. Taylor ; Hon. Secretary, Lewis Eynon.

\section{The Ray Society}

AT the annual general meeting of the Ray Society held on March 5, under the presidency of Sir Sidney Harmer, Lieut.-Colonel R. B. Seymour Sewell was elected a vice-president and Sir David Prain, Dr. R. W. T. Gunther (since deceased) and Mr. C. S. Todd new members of 
council. It was announced that the first volume of Prof. F. Balfour-Browne's "British Water Beetles" would shortly be issued to subscribers for 1939. The council, in its annual report, referred to the difficulties with which the Society is faced as a result of the War. The report continues : "The Council believe, however, that the work of the Society ought to be carried on as far as it is possible to do so in war time. In common with other scientific bodies, the Society has a definite function to perform in helping to maintain the continuity of our national life, of which its activities are a very small, but, as the Council believe, not a wholly negligible part. It is proposed therefore to go on with the publication of the works now being prepared, and the Council appeals to all members who are able to do so to continue their support of the Society."

\section{Association of Scientific Workers: New Branch}

THE recently formed Glasgow branch of the Association of Scientific Workers held its inaugural meeting in the Royal Technical College, Glasgow, on March 6. The proceedings opened with a display of films portraying the history of the vitamins and developments in the use of the cathode ray oscillograph. Dr. J. D. Sutherland, chairman of the branch, referred briefly to the aims and work of the Association and then called upon Prof. W. F. K. Wynne-Jones to deliver the inaugural address. Prof. Wynne-Jones led up to the general question of the organization of science and scientific workers by considering the planning of research. He said he is strongly opposed to the view that research should not be organized, and expressed the opinion that valuable results will only be obtained from an investigation if it is carefully planned beforehand. $\mathrm{He}$ contended that scientific research arises fundamentally from the needs of society, and illustrated his point with several very pertinent examples from the history of science. In furtherance of his argument for increased organization among scientific workers, Prof. Wynne-Jones spoke of the poor financial support received by research in Great Britain and of the muddles that had arisen at the outset of the War because men of science had not been called upon to organize services which belonged essentially to their province. Science can and must be organized, and to this end scientific workers must develop a corporate sense.

\section{Rhodes Scholarships for India}

THE Rhodes Trustees have decided to found two Rhodes Scholarships annually for India. The Rhodes Scholarships are of the annual value of $£ 400$, and tenable at the University of Oxford. With one or two exceptions they are awarded to young men who have been educated at universities in the British Dominions or in the United States of America. Cecil Rhodes laid down in his will that in the election of a scholar special regard should be paid to his scholastic attainments, his fondness for manly outdoor sports, his qualities of manhood, truth, courage, devotion to duty, unselfishness and sympathy for the weak, and his powers of leadership. The Rhodes Trustees are confident that candidates fully up to the high standard set by previous Rhodes Scholars will be forthcoming from India, and they have been assured that Indian Rhodes Scholars will be welcome at Oxford. These scholarships are founded for an initial period of five years, after which they will be reviewed in the light of experience. The first Indian Rhodes Scholars will go into residence at Oxford after the end of the War. This is the second announcement of post-graduate awards for Indian students which have been made in recent years; it will be recalled that the Commissioners of the Exhibition of 1851 instituted exhibitions for India in 1937.

\section{The Conception of the Atomic Clock}

The presidential address to the Section of Physies of the American Association for the Advancement of Science, which was delivered at Columbus on December 29 by Dr. Herbert E. Ives, is printed in Science $(91,79 ; 1940)$. The address is entitled "The Measurement of Velocity with Atomic Clocks". Taking the variation of atomic clock rate as an experimental fact, established by the Doppler effect in hydrogen canal rays, and adopting also the Fitzgerald contraction of moving rods indicated by the MichelsonMorley experiment, Dr. Ives points out that it is possible to define 'velocity' in various ways, none of which has any a priori claim to be chosen as 'correct'. The Restricted Theory of Relativity corresponds to the choice of one of them. "They are all deviations from the simple Newtonian concept of velocity", says Dr. Ives, "which is in terms of rods and clocks which are unaffected by motion. I urge the merit of the Newtonian framework as the only unambiguous basis for the idea of velocity". Dr. Ives does not consider that the ether has been "abolished" simply because it is possible to define velocity in a manner which makes it unnecessary to refer to that medium : he claims that the Sagnac experiment, in which beams of light moving in opposite directions round a rotating disk produce movable interference fringes, gives experimental evidence of the existence of the ether. His views, he says, "will be recognised as those of the earlier students of the subject-Fitzgerald, Larmor, Lorentz-but not of those who would shift the burden from variant measuring instruments to the nature of space and time".

Relativists will probably not be convinced by Dr. Ives's arguments. They will ask why, if there are invariant measuring rods and clocks, we cannot discover them but have to use those which vary with motion ; and further, why, of varying ones, we cannot tell in what state they approximate most closely to those which are immutable. It is to be noted also that Dr. Ives's address scarcely justifies the choice of title. An atom may be conceived as a clock, but cannot possibly be used as an instrument for measuring time or velocity unless we make an ad hoc definition of velocity in terms of wave-length changes and define an atom as a light-wave. 